\title{
Kearifan Sosial Masyarakat Sasak Melalui Tradisi Melampak di Kecamatan Lingsar Lombok Barat
}

\author{
Zaenudin Mansyur \\ Universitas Islam Negeri Mataram, NTB, Indonesia \\ email: zain_nahwa@yahoo.com
}

\begin{abstract}
The melampak tradition is one of the unique traditions practiced by the Sasak people in Lingsar District, West Lombok. Its uniqueness is evidenced by the stages of its implementation outside of the habits of other people in the ceremony of death. It is a tradition that has taken root in society which is marked by the spirit of the community in preserving it. Social sanctions in the form of ridicule, dislike, and hostility are the result of people who do not practice it. The initial stage is carried out by providing ritual tools such as potpourri, kembang rampai, dulang/andang-andang, air wangi, lekesan, beras putek, kemek, kepeng tepong, kemenyan.. Furthermore, it is carried out with a roah accompanied by the supply of goods according to the needs of the deceased during his life and then brought to the kiyai house who has been taking care of the body as a stage of the closing process. Disappearance or melampak tradition in the event of this death has been running steadily in the community because it is driven by the community's concern that this tradition will be lost, the heritage of ancestors, and education of the value of mutual cooperation. Thus, this tradition can not be claimed to develop as activities that deviate from the values of sayariah even theologically it is still sourced from the laws of the Shari'ah al-Qur'an and al-Hadith. Then sociologically the practice activities of outbreak can encourage the spirit of community social practices such as mutual cooperation, silaturrahim, and help. While anthropologically, this tradition is the legacy of ancestors who continue to strengthen the family atmosphere in society.
\end{abstract}

Keywords: Social Wisdom, Society, Sasak Tribe, Tradition, Outcast, Theological, Sociological, Anthropological.

\begin{tabular}{|c|c|c|}
\hline First Receive: & Revised: & $\begin{array}{c}\text { Accepted: } \\
\text { 25 Agustus 2019 }\end{array}$ \\
\hline $\begin{array}{c}\text { Final Proof Recieved: } \\
\text { 2 November 2019 }\end{array}$ & 10 September 2019 & Published: \\
\hline \multicolumn{3}{|c|}{ How to cite (in APA style): } \\
$\begin{array}{c}\text { Mansyur, Z. (2019). Kearifan Sosial Masyarakat Sasak Melalui Tradisi Melampak di } \\
\text { Kecamatan Lingsar Lombok Barat. Schemata, 8 (2), 35-46 }\end{array}$ \\
\hline
\end{tabular}

\section{PENDAHULUAN}

Manusia bukan personal pribadi atau makhluk individu, melainkan makhluk sosial. Mereka bergaul, berinteraksi, saling membutuhkan satu dengan lainnya. Dalam konsep ini terjelmalah komunitas atau kelompok yang kerapkali disebut dengan masyarakat. ${ }^{93}$ Terbentuknya suatu kehidupan yang harmonis dalam masyarakat tidak bisa lepas dari suatu

93 Masyarakat dalam perspektif ilmu sosiologi lazim diistilahkan sebagai kategori sosial, golongan sosial, komunitas, kelompok, dan perkumpulan. Dengan demikian istilah masyarakat dapat didefinisikan sebagai suatu kesatuan hidup manusia yang menempati suatu wilayah yang nyata, dan berinteraksi secara kontinyu sesuai dengan sistem adat istiadat, dan terikat oleh suatu rasa identitas komunitas. Jl. Gillin, Cultural Sociology (Chicago: University Of Chicago Press, 1954), 139. Bandingkan dengan R.M. Mclever dan C.H. Page Society: An Introduktory Analysis (New York: Rineheart an Company 1937), 8-9. Lihat juga Sidik Tono dkk, Ibadab dan Akblak dalam Islam (Yogyakarta: UII Press, 1998), 59. 
Zaenudin Mansyur, Kearifan Sosial Masyarakat Sasak. Melalui Tradisi Melampak di Kecamatan Lingsar...

aturan, norma, dan adat istiadat yang menata tata kehidupan serta aktivitas mereka. Adanya suatu aturan atau norma yang berlaku dikarenakan oleh adanya kebiasaan atau kebudayaan yang telah terbentuk dengan sendirinya melalui pergaulan yang mereka praktekkan. ${ }^{94}$

Peraturan yang berupa kaedah-kaedah dan nilai yang cenderung mengatur kehidupan manusia dalam masyarakat sangat bermacam ragamnya. Dari sekian banyak kaedah-kaedah tersebut terdapat kaedah yang terpenting, yaitu kaedah agama, di samping kaedah hukum, kesusilaan, dan kesopanan. Kaedah dan pola hukum dapat dijumpai dalam setiap kehidupan masyarakat tanpa adanya perbedaan letak penggunaan kaedah tersebut, baik di dalam masyarakat modern maupun tradisional, walaupun kadang-kadang warga masyarakat yang diatur tidak menyadari. Biasanya masyarakat baru menyadari akan adanya kaedah-kaedah hukum serta pola-pola yang mengatur kehidupannya apabila ia melakukan suatu pelanggaran. ${ }^{95}$ Masyarakat dalam segala pergaulannya sangat banyak membutuhkan agama, karena dalam agama mengandung kaedah-kaedah hukum yang bertujuan untuk mengatur masyarakat dalam menjalankan ketentuan-ketentuan agama Dengan demikian, tidak ironis ketika hukum dan agama dalam masyarakat tidak dapat dipisahkan. Masyarakat sebagai sebuah kelompok yang telah terikat dengan kaedah-kaedah hukum agama, tentu sangat menampakkan sikap militansi dalam berbagai aspek kehidupannya. ${ }^{96}$ Karena memang telah dirasuki oleh berbagai pola, jenis hukum yang muncul dari agama itu sendiri. Akan tetapi dari sisi yang lain masyarakat tradisional masih banyak memegang erat adat istiadat semenjak mereka lahir tanpa dipengaruhi oleh faktor-faktor dari luar, sehingga hukum, aturan yang lahir dari budaya dan adat istiadat tetap mereka pertahankan bahkan menjadi pedoman hidupnya. ${ }^{97}$

Adapun praktik adat kebiasaan yang masih dipertahankan oleh masyarakat suku Sasak yang bermukim di wilayah Kecamatan Lingsar adalah praktek melampak dalam

94 Kebiasaan atau kebudayaan adalah salah satu faktor yang dapat membentuk nilai atau norma dalam masyarakat karena masing-masing personal itu sejak kecil diresapi dengan nilai-nilai budaya yang hidup dalam masyarakatnya, sehingga konsep-konsep sejak lama telah berakar dalam pikiran dan jiwa mereka. Konsep semacam ini telah dapat menghantarkan perhatian para ahli budaya dalam mengambil kesimpulan bahwa nilai-nilai budaya yang telah mengakar sekali-kali tidak akan bisa dihganti dengan nilai-nilai budaya yang lain dalam waktu yang singkat, dengan cara mendiskusikannya secara rasional. Di samping itu budaya sistem gagasan, tindakan serta hasil karya manusia dalam rangka kehidupan masyarakat yang dijadikan milik manusia dengan belajar. Lihat Koentjoroningrat, Pengantar Ilmu Antropologi, cet. V (Jakarta: Reneka Cipta, 1990), 180. bandingkan juga dengan A. Hoebel, Man in The Frimitif World An Introduction (New York: Mc. Gam Hill, 1959), 152-153.

${ }^{95}$ Soerjono Soekanto, Pokok - Pokok Sosiologi Hukum (Jakarta: PT. Raja Grapindo Persada, 2004), 2.

${ }_{96}$ Dafid Berry, Pokok-Pokok Pikiran dalam Sosiologi, dalam Norma-Norma dan Perubahan Sosial (Jakarta: PT. Raja Grapindo Persada, 2003), 70. Lihat juga Robert K. Merton, Social Theory and Social Structure (New York: Free Press, 1968), 64-65.

${ }^{97}$ Ibid., 71.

\section{Copyright (C) 2019 Schemata Journal}

Available online at http://journal.uinmataram.ac.id/index.php/schemata 
Zaenudin Mansyur, Kearifan Sosial Masyarakat Sasak. Melalui Tradisi Melampak di Kecamatan Lingsar...

upacara kematian. Di mana praktek ini ditunjukkan sifat menariknya dengan pemberian barang kebutuhan si mayat di waktu hidupnya oleh keluarga yang ditinggalkan (sabib almusibah) kepada kiyai ${ }^{98}$ yang sudah mengurus prosesi upacara kematiannya. Tradisi ini telah berjalan secara turun temurun bahkan diberlakukan berulang kali dalam masyarakat, seolah menjadi sebuah aturan yang tidak boleh ditinggalkan dan berlaku ajeg dalam masyarakat suku Sasak di Kecamatan Lingsar. Bahkan menjadi korban cemoohan bagi semua keluarga yang ditinggalkan apabila tradisi ini tidak dilaksanakan. Dalam mempertahankan adat kebiasaan melampak ini, tokoh adat dan tokoh masyarakat secara bersama-sama membentuk aturan yang ekstra ketat dengan cara mengkaitkannya dengan tata tertib adat yang masih dijaga dan diperthankan. Hal itu dilakukan agar terhindar dari pelanggaran yang memalukan dan menjatuhkan martabat serta kehormatan keluarga yang ditinggalkan (sabib al-musibah). Karena itu, dalam praktek melampak itu dipandang perlu adanya sebuah aturan teknis demi tercapainya keamanan dan ketentraman dalam kehidupan masyarakat.

Nampaknya sebagian besar masyarakat yang berdomisili di wilayah Kecamatan Lingsar masih mempertahankan adat kebiasaan melampak ini. Hal ini dapat dibuktikan dari pengakuan salah seorang tokoh agama terhormat di wilayah tersebut. Ia menyatakan bahwa, masyarakat yang tersebar di masing-masin Desa masih banyak ditemukan tradisi melampak dalam upacara kematian. Terutama bagi Lingkungan yang tidak terbiasa meninggalkan tradisi lokal dalam berbagai upacara ritual keagamaan. ${ }^{99}$ Misalnya di wilayah Desa Lingsar sendiri, Desa Karang Bayan, Desa Sigrongan, Desa Geria, Desa Gegerung, Desa Duman, Desa Langko, dan lain-lain. Padahal masing masing wilayah di Kecamatan ini memiliki masyarakat yang tidak sedikit menunjukkan sikap cultural shoc tentang kesempurnaan agama yang dipegangnya. ${ }^{100}$ Bahkan sebagian besar juga mengklaim diri telah meninggalkan tradisi peninggalan nenek moyang yang dapat menghantarkannya pada

${ }_{98}$ Kiyai menurut tradisi masyarakat wetu telu berbeda dengan persepsi yang lazim diutarakan oleh masyarakat Suku Jawa adalah orang yang dituakan, memilki karismatik yang tinggi, dan sangat menguasai ilmu agama. Bedanya dengan persepsi orang suku Sasak karena masyarakat menganggap bahwa kiyai itu merupakan sekelompok atau beberapa orang tertentu yang dianggap sedikit bisa tentang agama. Wawancara dengan H. Mujiburrohman tokoh Agama Lingsar tanggal 21 Mei 2015.

99 Wawancara dengan tokoh adat Desa Karang Bayan Bapak Rinalim tanggal $24 \quad$ Mei 2015.

100 Culture shock didefinisikan sebagai kegelisahan yang mengendap yang muncul dari kehilangan tanda-tanda dan lambang-lambang yang familiar dalam hubungan sosial. Tanda-tanda atau petunjuk-petunjuk itu meliputi seribu satu cara yang kita lakukan dalam mengendalikan diri kita sendiri dalam menghadapi situasi sehari-hari. Mulyana, Deddy dan Jalaluddin Rakhmat, Komunikasi Antarbudaya Panduan Berkomuniaksi Dengan Orang-Orang Berbeda Budaya (Bandung: PT Remaja Rosdakary, 2005), 174.

\section{Copyright $\odot 2019$ Schemata Journal}

Available online at http://journal.uinmataram.ac.id/index.php/schemata 
Zaenudin Mansyur, Kearifan Sosial Masyarakat Sasak Melalui Tradisi Melampak di Kecamatan Lingsar...

kepercayaan mistis dan tidak logis seperti animisme, dinamisme, dan politeisme. ${ }^{101} \mathrm{Hal}$ ini dapat dibuktikan dari kondisi masyarakatnya semakin tergilas oleh pengaruh Tuan Guru yang melancarkan da`wah di sekitar itu. Begitu juga dengan adanya lembaga-lembaga pendidikan formal maupun non-formal yang terus proaktif dalam membangun masyarakat tradisional turut merampingkan pola pikir masyarakat yang bermukim di wilayah Kecamatan Lngsar ini. Berbagai macam tayangan media teknologi dan informasi yang kian hari semakin canggih dan modern juga tidak absent untuk mendinamisasikan idealitas, wawasan, dan gagasan ke arah yang logis dan argumentatif. Apalagi masyarakatnya masih tabu dalam menciptakan sarana prasarana untuk menolak modernisasi itu. Bahkan sebagian besar masyarakat belum memiliki wadah yang dapat memfilter arus globalisasi, sehingga tidak ironis kalau memaksa masyarakatnya untuk adaftif terhadap perkembangan zaman itu. Namun demikian praktek tradisi nenek moyang yang telah mereka wariskan masih banyak dipraktekkannya. Misalnya, perang topat, praje, selamet gumi dan yang tidak kalah pentingnya adalah tradisi melampak dalam acara kematian yang sampai saat ini dan seterusnya akan tetap dipertahankan oleh masyarakat Muslim Sasak di Kecamatan Lingsar ini.

Selain itu, mayoritas masyarakat muslim Sasak yang mermukim di Kecamatan Lingsar bermazhab Syafi $i$ yang nota benenya mengharamkan kegiatan-kegiatan yang memberatkan pihak yang terkena musibah. ${ }^{102}$ Apalagi kalau sampai masyarakat muslim Sasak itu mempraktikkan tradisi melampak. Karena tradisi ini sangat memberatkan keluarga yang ditinggalkan. Segala kebutuhan yang telah memenuhi syarat untuk dijadikan barang pemberian kepada seseorang yang dianggap Kiyai itu belum tentu bisa dipenuhi oleh keluarga. Karena sifat, jenis, kuantitas, dan kualitas yang sama belum tentu bisa diperoleh di zaman yang berbeda. Hal ini setidaknya memberatkan bagi pihak yang terkena musibah

101 Konsep individualisme memiliki pengertian (terms) ganda. (1) sebagai doktrin yang berkaitan dengan liberalisme yang menekankan pada kemandirian (autonomy), kepentingan (importance), dan kebebasan (freedom) individu dalam hubungan dengan masyarakat dan negara. (2) individualisme juga dipahami sebagai budaya dalam masyarakat modern yang berkaitan dengan kepemilikan pribadi (private property), konsumsi, dan subjektivitas. George Ritzer, ed. Encyclopedia of Social Theory, Vol. 1. Sage Publications, Thousand Oaks, London, 2004.

102 Madzhab Syafi'i memandang bahwa perbuatan keluarga mayat yang membuat makanan agar orang-orang berkumpul di rumah keluarga mayat adalah perkara bid'ah. Hal ini dapat dicermati dari

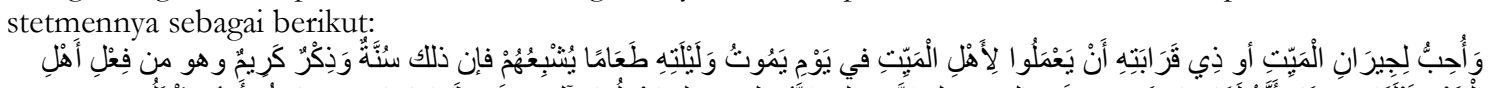

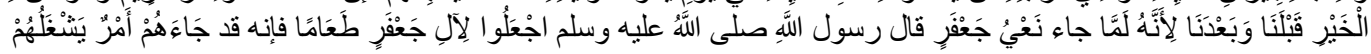
"Dan aku menyukai jika para tetangga mayat atau para kerabatnya untuk membuat makanan bagi keluarga mayat yang mengenyangkan mereka pada siang dan malam hari kematian sang mayat. Karena hal ini adalah sunnah dan bentuk kebaikan, dan ini merupakan perbuatan orang-orang baik sebelum kami dan sesudah kami, karena tatkala datang kabar tentang kematian Ja'far maka Rasulullah shallallahu 'alaihi wa sallam bersabda, "Buatkanlah makanan untuk keluarga Ja'afar, karena telah datang kepada mereka perkara yang menyibukkan mereka"Lihat Al Hafidz Ibnu Hajar Nuzhatun Nadhor jilid 1 (Riyadh: Matba'ah Safiir, t.th), 237.

\section{Copyright (C) 2019 Schemata Journal}

Available online at http://journal.uinmataram.ac.id/index.php/schemata 
Zaenudin Mansyur, Kearifan Sosial Masyarakat Sasak Melalui Tradisi Melampak di Kecamatan Lingsar...

tersebut. Misalnya tradisi melampak yang dipraktekkan oleh Rabi ah salah seorang warga di Desa Langko Kecamatan Lingsar Lombok Barat Nusa Tenggara Barat yang telah ditinggal mati oleh Suaminya. Pada saat mengeluarkan barang paelampaan itu ia merasa kesulitan dalam mencari barang yang telah dibutuhkan oleh almarhum suaminya. Menurutnya barang yang paling sulit untuk dipenuhi adalah barang yang sudah tidak diproduk lagi oleh perusahaan. ${ }^{103}$

Bertitik tolak dari uraian di atas dapat ditarik sebuah gambaran bahwa tradisi melampak dalam upacara kematian yang dipraktekkan masyarakat suku Sasak di Kecamatan Lingsar Lombok Barat itu, telah terjadi kesenjangan bila mencermati kondisi masyarakatnya yang sudah mengklaim diri sebagai penganut agama sempurna yang nota benenya sejak lama telah meninggalkan adat kebiasan nenek moyangnya yang berbau mistis. Begitu juga, Mazhab Syafi i sebagai mazhab mayoritas yang telah jelas mengharamkan praktek-praktek yang dapat memberatkan keluarga yang ditinggal mati. Sisi lain yang tidak kalah pentingnya untuk dilakukan sebuah penelitian ini adalah peristiwa unik yang ditunjukkan oleh masyarakat Rasionalis modernis yang tinggal di wilayah perumahan-perumahan baru, turut aktif dalam mempraktekkan tradisi melampak ini. Realitas ini membuktikan bahwa tradisi melampak ini tidak hanya dipraktekkan oleh kalangan muslim tradisional saja tetapi lebih luas lagi pada masyarakat modern yang lazim menonjolkan sikap rasional, logis, dan modern juga tidak sedikit mempraktekknya. Sedang sisi lain masyarakat muslim yang bermukim di wilayah Kecamatan Lingsar ini menjadikan Mazhab Syafi i sebagai mazhab mayoritas yang seharusnya mengikuti statemen yang dilontarkan oleh Imam Syafi i tentang keharaman seseorang muslim memberatkan saudara muslim lainnya ketika menghadapi musibah kematian seperti halnya praktek tradisi melampak itu. Meskipun demikian praktek tradisi melampak seakan menjadi kewajiban yang tidak boleh ditinggalkan dalam upacara kematian. Hal inilah menjadi sisi menariknya untuk dilakukan kajian mendalam tentang persoalan ini agar terjawab pertanyaan tentang bagimana praktek upacara kematian, melampak serta faktor yang melatarinya bagi masyarakat suku Sasak di Kecamatan Lingsar Lombok Barat?

\section{METODE PENELITIAN}

Jenis penelitian yang digunakan dalam penelitian ini adalah penelitian kualitatif yang berusaha menghasilkan data deskriptif berupa tulisan atau lisan dari orang-orang dan

${ }^{103}$ Wawancara dengan Rabi ah Warga Desa Langko Kecamatan Lingsar, tanggal 9 Maret 2015. 
Zaenudin Mansyur, Kearifan Sosial Masyarakat Sasak Melalui Tradisi Melampak di Kecamatan Lingsar...

perilaku yang dapat diamati. ${ }^{104}$ Adapun kualitatif yang dimaksud dalam penelitian ini adalah mengkaji dan mendiskripsikan data lapangan yang terkait dengan praktek tradisi melampak dalam upacara kematian di internal masyarakat suku Sasak sebagai kearifan sosial di Kecamatan Lingsar Lombok Barat. Artinya seluruh data lapangan yang telah diperoleh sesuai dengan obyek kajian ini akan didiskripsikan apa adanya sehingga dapat diklaim sebagai penelitian empiris sebagaimana yang diungkap oleh Atho Muzhar. ${ }^{105}$ Sementara pendekatan yang digunakan adalah pendekatan antropologis. ${ }^{106}$ Pendekatan antropologis dimaksudkan dalam penelitian ini adalah mengkaji dan menelusuri praktek melampak itu dari sisi budaya, yakni peneliti terjun langsung di lapangan dalam rangka mengikuti upacara kematian itu. Selain itu, peniliti berupaya melakukan penelitian dengan pendekatan sosial, yakni peneliti mencoba bergaul bersama maysrakat layaknya penduduk yang berdomisili di Kecamatan Lingsar. Hal ini dilakukan dalam rangka mempermudah peneliti untuk mendapatkan data yang dibutuhkan di lapangan.

Mengenai teknis pengumpulan data digunakan teknik observasi, wawancara, dan dokumentasi. ${ }^{107}$ Obesrvasi dilakukan dalam rangka mengamati kondisi lapangan sekaligus menetapkan lokasi yang masyarakatnya mempraktekkan tradisi melampak itu di Kecamatan Lingsar Lombok Barat. Sementara wawancara digunakan untuk mewawancarai masyarakat apakah sebagai tokoh adat, tokoh agama, dan pelaku dari traidisi melampak tersebut baik kapasitasnya sebagai responden maupun informan. Adapun informan inti dalam penelitian ini adalah para pelaku serta tokoh-tokoh sentral yang langsung melegalkan tradisi melampak itu dalam masyarakat. Tokoh sentral yang dimaksud adalah tokoh agama karena merekalah sebagai dalang atau pemimipin dalam melegalkan praktek melampak tersebut. Sedangkan dokumentasi dibutuhkan untuk menggali data dari tulisan baik berupa buku, majalah, jurnal, taboloud yang ada kaitannya praktek tradisi melampak dalam upacara kematian pada masyarakat Kecamatan Lingsar Lombok Barat. Selain itu, dibutuhkan juga profil Kecamatan Lingsar sebagai tambahan dokumentasi serta dapat menambah data dan informasi dari penelitian ini sehingga datanya bersipat primer dan skunder.

Primer maksudnya data yang dihasilkan murni dari lapangan sesuai objek yang diteliti, yaitu data-data yang terkait dengan tradisi melampak dalam upacara kematian di

\footnotetext{
104 Irwan Suhartono, Metode Penelitian Sosial (Bandung:Remaja Rosdakarya, 1998), 50.

105 Penelitian ini dapat di lihat dalam Atho Mudzhar, Studi Hukum Islam dengan Pendekatan Sosiologis (Yogyakarta:IAIN Sunan Kalijaga Press, 1999), 6.

106 Irwan Suhartono, Metode Penelitian Sosial (Bandung:Remaja Rosdakarya, 1998), 52.

107 Adapun penjelasan mengenai teknis pengumpulan data tersebut dapat di lihat dalam buku buku metodologi penelitian. Salah satunya adalah Irwan Suhartono, Metode..., 67.
}

Copyright (C) 2019 Schemata Journal

Available online at http://journal.uinmataram.ac.id/index.php/schemata 
Zaenudin Mansyur, Kearifan Sosial Masyarakat Sasak Melalui Tradisi Melampak di Kecamatan Lingsar...

internal masyarakat muslim Sasak sebagai wujud kearifan sosial di Kecamatan Lingsar Lombok Barat. Sedangkan sekunder artinya sumber data yang berasal dari literatur berupa pendapat-pendapat sarjana, pemuka agama, tokoh adat, dan yang terkait dengan masalah yang diteliti. ${ }^{108}$ Dari sekian responden yang ada tokoh agama merupakan tokoh sentral yang dijadikan sebagai responden utama karena sangat terkait dengan bidangnya, yaitu bidang upacara spiritual keagamaan. Tidak terkecuali pratek sedekah atau melampak yang lazim dipraktekkan oleh masyarakat yang berdomisili di daerah Kecamatan Lingsar Lombok Barat. Dengan demikian, pengukuran validitas data yang diperoleh digunakan pisau analisis, yaitu diskriptif dan induktif ${ }^{109}$ serta teori yang relevan seperti teori Sosial Clifford Geertz, ${ }^{110}$ dan adat kebiasaan $(u r f)^{111}$ secara bergiliran ditampilkan sebagai pisau bedah dalam penelitian ini.

\section{HASIL DAN PEMBAHASAN}

\section{Melampak Sebagai Tradisi Sosial Masyarakat}

Sedekah di internal kaum muslimin merupakan aktivitas sosial yang sudah tidak asing. Ia merupakan tuntutan agama yang tidak bisa ditinggalkan bahkan menjadi perkara yang wajib untuk mendorong sirkulasi keadilan ekonomi dalam masyarakat. Di samping itu, secara sosial teologis sedekah merupakan perwujudan hamba yang taat terhadap perintah Tuhan sekaligus sebagai sarana untuk memenuhi kebutuhan masyarakat yang satu dengan masyarakat lainnnya yang di situ masih terdapat kekurangan. Aktivitas sedekah sebagai sarana sosial dalam masyarakat, setidaknya menjadi suatu aktivitas yang tidak

108 Soerjono Soekanto, Pengantar Penelitian Hukum (Jakarta: UII Press, 1986), 12.

109 Deduktif dimaksudkan untuk menganalisa masalah tradisi upacara kematian di internal masyarakat Sasak baru di susun dengan materi praktek tradisi melampak kemudian dianalisis sampai pada tahap menyimulkan sehingga termenologi mengenai analisa induktif dapat dipergunakan secara sempurna. Begitu juga dihajatkan dengan menggunakan analisa induktif, yaitu menganalisa data dari praktik yang dilakukan oleh masyarakat yang berhubungan dengan praktek tradisi melampak dalam acara kematian di Kecamatan Lingsar sehingga dapat berbentuk teori secara umum. Lihat Irwan Suhartono, Metode..., 5.

${ }_{110}$ Agama sebagai aspek tertentu menstrukturkan kebudayaan, tetapi agama juga dilihat sebagai pedoman bagi ketepatan dari kebudayaan, suatu pedoman yang beroperasi melalui sistem-sistem simbol pada tingkat emosional, kognitif, subyektif, dan individual. Clifford Geertz, The Interpretation of Culture (New York: Basic Group, 1973), 89.

111 Dalam ilmu ushul fiqib kebiasaan masyarakat disebut juga dengan urf. Urf secara etimoologi bararti sesuatu yang dipandang baik, yang diterima akal sehat. Menurut kebanyakan ulama, urf dinamakan juga adat, sebab perkara yang sudah dikenal berulang-ulang kali dilakukan. Dalam hukum Islam tradisi yang dikenal dengan sebutan urf, merupakan bentuk-bentuk perbuatan yang telah berlangsung berualng-ulang ditengahtengah masyarakat, dan ini merupkan suatu sumber yang diambil oleh mazhab Maliki dan Hanafi yang berada dalam ruang lingkup nash. Urf merupakan bagian adat, karena adat lebih umum dari urf. Urf berlaku pada kebanyakan orang di daerah tertentu dan urf bukanlah kebiasaan alami sebagaimana yang berlaku dalam kebanyakan adat, tetapi muncul dari suatu pemikiran dan pengalaman. Lihat Muhammad Salim Mazkur, Madkhal Fiqih al-Islam (Kairo, Dar al-Qaumiyyah, 1964), 120. Bandingkan dengan Muhammad Abu Zahrah, Ushul Fiqh (Jakarta: Pustaka Pirdaus, 2003), 116.

\section{Copyright () 2019 Schemata Journal}

Available online at http://journal.uinmataram.ac.id/index.php/schemata 
Zaenudin Mansyur, Kearifan Sosial Masyarakat Sasak Melalui Tradisi Melampak di Kecamatan Lingsar...

mengherankan jika dipraktekkan oleh masyarakat di masing-masing Desa maupun Kecamatan tertentu. Misalnya dalam hal pengelolaan, baik dalam proses pengumpulan, penghimpunan, dan pendistribusiannya. Ada yang melaksanakannya dengan membentuk Badan Amil Zakas dan Sedekah (BAZIS), ada juga dilakukan oleh masing-masing internal keluarga, bahkan ada juga yang dilakukan dengan cara mensingkronkannnya dengan tradisi adat kebiasaan yang diterima dari nenek moyang. Kecamatan Lingsar yang bermayoritas muslim dapat diklaim masih cenderung memeprtahankan kearifan lokal dalam mempraktekkan tradisi sedekah.

Artinya praktek melampak lazim dikaitkan dengan kematian. Dengan demikian, tidak heran kalau kemudian lumrah disebut sebagai tradisi melampak atau sedekah upacara kematian. Prakteknya terbilang berlangsung sudah cukup lama. Wardi salah satu tokoh masyarakat Desa Karang Bayan mengaku bahwa praktek upacara melampak ini memang sudah ada sejak dia lahir dan belum mengetahui sejarah sebenarnya. Teknis pelaksanaannya biasa dilakukan setelah upacara sembilan hari kematian al-marbum. Adapun barang-barang yang dijadikan sebagai obyek melampak adalah barang-barang yang nota benenya menjadi kebutuhan al-marbum selama hidupnya bergaul dengan masyarakat. Kebutuhan tersebut berkisar pada kebutuhan primer dan sekunder saja. Misalnya beras, buah, laok, umbiumbian, sandal topi, kopiah, tikar, baju muslim, kain sarung, dan lain-lain. Semua barangbarang yang telah disediakan itu biasanya diberikan kepada kiyai yang mengurus jenazah almarbum itu. ${ }^{112}$

Tokoh agama lain juga tidak ketinggalan memberikan statemen yang tidak jauh berebeda, misalnya Sapturi yang berdomisili di wilayah Desa Saribaye menjelaskan bahwa praktek sedekah upacara kematian awalnya dilatar belakangi oleh sugesti dan motivasi masyarakat Sasak Lombok untuk mendapatkan keselamatan pada arwah yang sudah meninggal yang kemudian diungkapkan dengan doa dan pemujaan. Lalu menjadi kebiasaan yang diikuti oleh perubahan-perubahan ritual sesuai pengaruh agama dan kepercayaan yang ada. Termasuk pengaruh Hindu sebab dahulu Anak Agung Bali pernah menjajah Lombok selama puluhan tahun. ${ }^{113}$ Lebih jauh ia mengatakan bahwa selama ia berkuasa setidaknya telah banyak mempengaruhi pemikiran serta praktek keagamaan masyarakat Islam suku Sasak kala itu. Dengan demikian, tidak menjadi sesuatu yang asing jika masyarakat di

\footnotetext{
112 Wawancara dengan tokoh maysarakat, Wardi dari Desa Karang Bayan, 9 Juli 2015.

113 Wawancara dengan Sapturi tokoh masyarakat dari Desa Saribaye 9 Juli 20015. 
Zaenudin Mansyur, Kearifan Sosial Masyarakat Sasak Melalui Tradisi Melampak di Kecamatan Lingsar...

Kecamatan Lingsar masih kental dengan tradisi-tradisi lokal termasuk dalam mempraktekkan melampak dalam upacara kematian.

Pernyataan yang sama terlontar dari seorang tokoh pemudi di Desa Batu Mekar Kecamatan Lingsar. Ia menyatakan bahwa tradisi melampak merupakan aktivitas yang telah mengakar dipraktekkan oleh masyarakat setempat. Ketika peneliti mengkonfirmasi lebih jauh, ia hanya menyatakan kebiasan tersebut telah dipraktekkan dari sejak dahulu oleh para leluhur. Menurutnya bahwa tradisi melampak dalam upacara kematian yang telah ditemukannya merupakan kegiatan yang tidak pernah diketahui oleh masyarakat sejak kapan dimulai. Lebih jauh Rinipti memebrikan informasi bahwa persoalan sedekah ini merupakan kegiatan-kegiatan biasa saja yang tidak menyimpang dari aturan agama. Tujuan untuk diadakannya melampak kematian ini dalam rangka menyedekahkan harta kebutuhan dari al-marbum sehingga diharapkan pahalanya bisa terkirimkan kepadanya. Sedangkan barang yang dijadikan sebagai sarana melampak itu adalah seperti yang diuangkapkan oleh dua tokoh agama sebelumnya. Semua peralatan melampak ditempatkan di satu tempat kemudian biasa diserahkan kepada Kiyai yang mengurusi jenazah al-marbum. ${ }^{114}$

Pernyataan melampak sebagai tradisi nenek moyang adalah menjadi alasan yang lazim muncul dari kalangan masyarakat Lingsar. Mislanya tokoh agama yang berasal Dari Desa Duman H. Burhanudin. Ia memberikn informasi tentang tradisi melampak yang lazim dipraktekkan masyarakat desa merupakan tradisi yang tidak bisa rampingkan dalam masyarakat Sasak khususnnya masyarakat Kecamatan Lingsar. Masing-masing masyarakat rata-rata mempraktekkannya. Tetapi dalam proses pelaksanaan terjadi perbedaan ada yang melaksanakannya dengan cara besar-besaran ada juga yang melaksanakannya dengan sesederhana mungkin. H. Burhanudin menyimpulkan bahwa tradisi melampak ini merupakan sedekah yang diniatkan pahalannya untuk orang yang telah meninggal dunia. Karena itu, upacara pelaksanaannya sangat tergantung dari kemampuan masing-masing keluarga. Semua barang yang menjadi alat melampak diberikan kepada orang-orang yang tidak mampu dalam masyarakat itu. ${ }^{115}$

Statemen yang sama dapat dilontarkan juga oleh seorang tokoh agama di Desa Langko, yaitu Ustaz Fikri. Melampak yang kerap dipraktekkan oleh masyarakat merupakan sedekah yang diniatkan pahalannya semata-mata bagi keluarga yang telah meninggal dunia. Ia lebih jauh mengungkapkan bahwa di wiliayah Desa Langko tidak sedikit dari kalangan

114 Wawancara dengan Rinipti tokoh pemuda dari Desa Batu Mekar 12 Juli 20015

115 Wawancara dengan H. Burhanudin tokoh agama dari Desa Duman 12 Juli 20015. 
Zaenudin Mansyur, Kearifan Sosial Masyarakat Sasak. Melalui Tradisi Melampak di Kecamatan Lingsar...

masyarakat lazim mempraktekkannya. Praktek melampak ini semestinya harus terus dilestarikan karena memberikan manfaat dan maslahat kepada masyarakat penerima. Di samping itu juga memberikan kontribusi dalam melatih atau membiasakan masyarakat untuk melakukan tradisi sosial. Apalagi kalau seumur hidup yang meninggal jarang memberikan sedekah dan infaq kepada yang membutuhkan. Dengan demikian, menurut Ustaz Fikri ini tidak ditentukan bahkan tidak dibebani berapa yang harus dikeluarkan dalam bentuk barang. Lebih jauh ia mengungkapkan bahwa kalau bisa pengeluaran melampak ini diharuskan dengan cara yang sangat sederhana agar keluarga yang ditinggalkan tidak merasa terbebani. Kebiasaan terakhir yang berlaku adalah semua barang-barang yang telah diniatkan untuk menjadi materi melampak itu diserahkan sepenuhnya kepada keluarga yang ditinggalkan. Terlepas mau diserahkan kepada kiyai, faqir miskin, orang tua jompo, duda, janda dan lain-lain. ${ }^{116}$

Dari statemen yang telah dilontarkan Ustaz Fikri itu, setidaknya dapat ditarik sebuah gambaran bahwa tradisi melampak dalam rangkaian upacara kematian yang diberikan kepada keluarga, tetangga, dan kiyai itu harus dilestarikan dengan sebaik-baiknya. Alasan yang kuat adalah pemberian pesangon kepada Kiyai dalam rangka membalas jasanya yang telah mentahlilkan serta mendoakannya selama pelaksanaan tahlilan sembilan hari. Selain itu, kegiatan keagamaan ini tidak terlalu berseberangan dengan aturan agama. Masyarakat pada dasarnya bebeas melakukan kebaikan namun yang menerima amal seseorang adalah yang Maha Kuasa itu. ${ }^{117}$ Dari alasan seperti ini, dapat ditarik sebuah gambaran bahwa praktek sedekah yang lazim disebut sebagai aktivitas melampak mendapat legalitas yang terus dibudayakan dalam masyarakat Kecamatan Lingsar terutama masyarakat yang berdomisli di masing-masing Desa setempat.

Selain itu, tokoh masyarakat Desa Saribaye memberikan respon tentang praktek melampak dalam upacara kematian. Ia menyatakan bahwa praktek ini tidak terlalu banyak dilakukan oleh masyarakat karena telah banyak dipengaruhi oleh pendidikan bahkan tidak sedikit yang menyelesaikan ke jenjang sarjana. Respon tokoh masyarakat ini sekaligus sebagai Kepala Desa di Desa tersebut bukan berarti menapikan sama sekali tentang praktek melampak di internal masyarakat itu. Artinya tidak sedikit telah lama meninggalkannya dan tidak sedikit juga yang terus mempraktekkannya. Alasan kuat yang melegalkan masyarakat terus melaksanakannya adalah di samping sebagai adat yang telah diterima secara turun

116 Wawancara dengan Usrtaz Fikri tokoh agama dari Desa Langko 13 Juli 20015.

117 Wawancara dengan Usrtaz Fikri tokoh agama dari Desa Langko 13 Juli 20015 
Zaenudin Mansyur, Kearifan Sosial Masyarakat Sasak Melalui Tradisi Melampak di Kecamatan Lingsar...

temurun juga sebagai sarana aktivitas sedekah yang diperuntukkan pahalanya kepada orang yang telah meninggal itu. ${ }^{118}$ Pernyataan berbeda dilontarkan oleh Ulul Azmi salah satu tokoh masyarakat Dusun Karang Bayan Barat mengatakan bahwa upacara selamatan dan pemberian barang tentu dalam rangkaian upacara kematian atau yang sering disebut melampak ini menurutnya berasal dari tanah Jawa. Ini dilandasi upacara selamatan kematian masyarakat Jawa yang sedikit mirip dengan yang dilakukan masyarakat Lombok. ${ }^{119}$

\section{Alat Ritual dan Proses Sedekah Kematian}

Dalam melakukan tradisi melampak dalam rangkaian upacara kematian ada beberapa alat ritual yang harus dipersiapkan terlebih dahulu, yaitu pertama, kembang rampai (bunga) yang beragam jenis bunga yang nantinya di campur air, namun tidak ditentukan jenis kembangnya. Kedua, dulang/andang-andang (hidangan), yaitu berupaka makanan-makanan yang ditaruh di depan kiyai dan masyarakat yang mengahdiri upacara tersebut. Ketiga, air wangi, yaitu air yang sudah didoakan oleh kiyai dan akan dituangkan di atas kuburan orang yang diniatkan. Keempat, lekesan/kelengkapan makan sirih, adalah sejenis makanan atau candu yang diisap yang terbuat dari campuran daun sirih, buah pinang, gambir dan kapur. Kelima, beras yang digunakan untuk campuran air wangi yang nantinya akan dituangkan di atas kuburan. Keenam, kendi, yaitu bejana yang terbuat dari tanah liat yang di bakar. Biasanya ditemukan di tempat pengrajin gerabah. Ketujuh, kepeng tepong (uang logam) adalah uang zaman dahulu yang di gunakan untuk pelengkap ditaruh di atas berugak.

\section{Prosesi Upacara Tradisi Melampak}

Upacara sedekah dalam rangkaian upacara kematian atau yang lazim disebut sebagai melampak dilakukan dengan beberapa prosesi. Sesuai dengan data yang peneliti peroleh di lapangan bahwa prosesi yang dapat dilaksanakan oleh masyarakat Kecamatan Lingsar adalah prosesi pembuka, prosesi inti dan prosesi penutup. Masing-masing prosesi ini akan dijelaskan secara rinci pada bahasan berikut ini;

Pertama, prosesi pembuka, yaitu upacara sedekah kematian atau melampak dimulai dengan acara zikiran (Roab) yang dihadiri oleh keluarga, tetangga, masyarakat dan tokoh agama yang dilakukan pada malam hari terhitung sejak hari pertama kematian sampai malam kesembilan. Zikiran berupa materi zikir dan tahlil yang biasa masyarakat Lombok yang lazim dibaca setelah shalat lima waktu yaitu pembacaan surat al-Iklas, surat al-Falaq, surat an-Nas, surat al-Fatihah dan Surat Al-Baqarah dari ayat satu sampai ayat lima Juli 2015.

118 Wawancara dengan Sarawan Sukadana Tokoh Masyarakat Desa Saribaye tanggal

119 Ulul Azmi, Wawancara, Karang Bayan, 12 april 2015.

Copyright $(92019$ Schemata Journal

Available online at http://journal.uinmataram.ac.id/index.php/schemata 
Zaenudin Mansyur, Kearifan Sosial Masyarakat Sasak Melalui Tradisi Melampak di Kecamatan Lingsar...

kemudian membaca kalimat tauhid laa ilaaha ilalloh sebanyak pimpinan zikir inginkan. Lalu dilanjutkan dengan doa. Setelah zikiran selesai, peserta zikir diberikan hidangan untuk dimakan di tempat yaitu berupa nasi lengkap dengan lauk-pauknya. Dan di saat-saat itu pula keluarga menyiapkan alat-alat ritual seperti kembang rampai (bunga), yang dicampur dengan air wangi yang sudah di doakan kiyai, dulang/andang-andang (hidangan), lekesan/kelengkapan makan sirih, paso tanaq (kendi), kepeng tepong (uang bolong), kemenyan serta barang-barang yang akan diserahkan kepada tokoh agama, tokoh masyarakat serta orang yang dianggap penting oleh keluarga si mayit. Kemudian di taruh bersama alat ritual lainnya di tempat yang sudah di sediakan keluarga di rumah si mayit.

Kedua, proses inti, yaitu setelah alat ritual disiapkan dan peserta zikir bubar, salah seorang keluarga memulai dengan membawa barang-barang yang telah diserahkan kepada tokoh agama, tokoh masyarakat serta orang yang dianggap penting untuk diberikan kepadanya sebagai imbalan karena telah mendoakan si mayit. Setelah itu dilanjutkan dengan pembagian barang-barang kesukaan si mayit semasa hidupnya oleh keluarga dan dibantu oleh tetangga-tetangga untuk dibawa kerumah orang yang telah dituju oleh keluarga si mayit, dengan tujuan untuk mendapat ketenangan dan keselamatan.

Ketiga, prosesi penutup adalah pembagian barang-barang sedekah dengan cara berjalan (lampak) menuju ke rumah kiyai, tokoh agama, dan tokoh masyarakat yang sudah dibacakan doa berupa barang-barang kesukaan si mayit semasa hidupnya dan akan di serahkan kepada orang yang sudah ditunjuk oleh keluarga si mayit. Kemudian setelah pembagian barang melampak sudah selesai dibagikan dan semua keluarga si mayit bersalaman di berugak menandakan bahwa rangkaian acara tersebut telah selesai dan diyakini akan mendapatkankebrekahan.

\section{Faktor-Faktor Yang Melatarbelakangi Praktek Melampak}

Bnayak alasan yang dapat peneliti tangkap ketika mengkonfirmasi tentang faktor yang melatarbelakangi praktek upacara ritual melampak dalam acara kematian di internal masyarakat Kecamatan Lingsar. Dari sekian hasil yang diperoleh tetapi ada tiga secara garis besar alasannya meskipun pada saat responden merespon peneliti dengan menggunakan bahasa yang variatif namun pada prinsipnya tidak jauh berbeda. Dengan demikian, berdasarkan hasil wawancara dengan beberapa warga Kecamatan Lingsar terutama di masing-maing Desa yang banyak mempraktekkannya secara besar-besaran adalah Karang Bayan. Mereka mengatakan bahwa faktor yang menyebabkan terjadinya praktek tradisi

\section{Copyright $(92019$ Schemata Journal}

Available online at http://journal.uinmataram.ac.id/index.php/schemata 
Zaenudin Mansyur, Kearifan Sosial Masyarakat Sasak Melalui Tradisi Melampak di Kecamatan Lingsar...

melampak dalam upacara kemaitian masih dilakukan sampai saat ini secara umum antara lain:

Pertama, rasa takut kehilangan. Rata-rata di masing Desa yang ada di Kecamatan Lingsar terutama di Masyarakat Desa Karang Bayan mengatakan bahwa praktek tradisi melampak dalam upacara kematian ini menjadi suatu kehwatiran masyarakat bahwa adat kebiasaan ini akan punah apabila tidak dilestarikan. Dalam pelaksanaan praktek melampak dalam upacara kematian di Desa Karang Bayan menurut beberapa informan mengungkapkan pandangan yang beragam. Misalnya menurut Janiman ${ }^{120}$ alasan melakukan praktek melampak upacara kematian yaitu karena rasa takut kehilangan adat yang sudah lama ada sejak zaman nenek moyang, apabila praktek melampak ditinggalkan maka masyarakat dianggap sebagai binatang karena binatang apabila sudah mati ya mati tidak di ingat lagi oleh keluarganya. Kehawatiran terhadap punahnya tradisi melampak atau upacara sedekah di Kecamatan Lingsar diungkapkan juga oleh Sapturi tokoh masyarakat Desa Langko. Ia menyatakan bahwa kegiatan ini harus dilestarikan karena dapat menumbuhkan rasa persaudaraan yang kental, terutama pihak keluarga yang memberikan dan masyarakat yang diberikan obyek melampak. Bahkan tidak terlalu jauh menyimpang dengan syari at Islam meskipun secara teologis tidak ada ditemukan baik dalam al-Qur`an, al-Hadis, maupun Fatwa Ulama. Pendapat yang sama dilontarkan oleh H. Mahsun sebagai tokoh masyarakat sekaligus tokoh agama. Ia menyatakan bahwa tradisi melampak atau sedekah yang telah dipraktekkan dalam upacara kematian adalah aktivitas yang sangat positif. Para pendahulu ataupun nenek moyang dalam menetapkan sesuatu pasti terdapat hikmah yang terkandung di dalamnya. Salah satu hikmah yang dapat dipetik dari praktek melampak ini adalah memperkuat jalinan silaturrahim antar sesama. Karena itu, melestarikan tradisi melampak ini menjadi tugas masyarakat yang tidak boleh ditinggalkan. Selain itu, juga dapat memperkuat hubungan silaturrahmi dan sebagai imbalan untuk mendukung keikhlasan Kiyai atau Nyai yang mengurus jenazah itu. ${ }^{121}$

Kedua, secara teologis bahwa aktivitas melampak tersebut sangat relevan dengan tujuan ditetapkan syari at itu, yaitu menjaga kemaslahatan dan kesejahteraan masyarakat. Setatemen ini tidak menjadi salah ketika mencermati ungkapan dari H. Radi ${ }^{122}$ bahwa praktek melampak atau sedekah ini masih tetap dilakukan karena salah satu budaya yang

120 Wawancara dengan Janiman Tokoh Masyarakat Karang Bayan 17 Juli 2015.

${ }^{121}$ Wawancara dengan H. Mahsun Tokoh Agama Desa Sigerongan tanggal 17 Juli 2015.

122 Wawancara dengan H. Radi tokoh masyarakat di Dusun Berembeng Timur Desa Karang Bayan tanggal 17 Juli 2015.

\section{Copyright () 2019 Schemata Journal}

Available online at http://journal.uinmataram.ac.id/index.php/schemata 
Zaenudin Mansyur, Kearifan Sosial Masyarakat Sasak Melalui Tradisi Melampak di Kecamatan Lingsar...

tidak bertentangan dengan agama karena di dalamnya terdapat ritual berupa doa dan zikir bersama. Munculnya praktik sedekah upacara kematian di latar belakangi oleh faktor adanya ketakutan masyarakat untuk meninggalkannya menyebabkan munculnya sugesti masyarakat untuk tetap melakukan tradisi ini. Karena menurut keyakinan masyarakat Kecamatan Lingsar, mayit akan di hapus dosanya dan masuk surga apabila dikirimkan pahala doa dan zikiran. Sementara kegiatan melampak ini merupakan upacara yang diawali dengan zikir dan do`a yang diniatkan khusus kepada al-marbum dan al-marbumah. Aktivitas melampak ini secara terus menerus dipraktekkan oleh masyarakat setempat sehingga lambat laun menjadi kebiasaan atau adat-istiadat yang diikuti oleh perubahan-perubahan ritual sesuai pengaruh agama dan kepercayaan yang ada. ${ }^{123}$

Ketiga, warisan nenek moyang. Pada umumnya manusia tidak bisa hidup sendiri tanpa bantuan orang lain, karena manusia saling membutuhkan satu sama lain. Dalam kehidupan sehari hari kadang-kadang masyarakat bergotong royong melakukan suatu hal yang positif. Misalnya aktivitas yang lazim dilaksanakan oleh masyarakat, yaitu tradisi melampak atau sedekah yang diperuntukkan pahalanya kepada yang meninggal dunia di saat upacara kematian. Keberadaan kasus melampak ini dapat dipraktekkan secara turun temurun oleh masyarakat Kecamatan Lingsar adalah disebabkan karena beberapa faktor, yaitu faktor rasa saling peduli terhadap sesama warisan nenek moyang, dan tradisi warisan yang baik sehingga tidak mungkin ditinggalkan. ${ }^{124} \quad$ Janiman mengatakan suatu adat yang telah diwariskan kepada anak cucunya tidak boleh ditinggalkan karena apabila di tinggalkan atau dihilangkan maka suatu masalah akan datang tiba-tiba baik berupa mala petaka ataupun sakit yang mungkin tidak langsung menimpa tetapi akan menimpanya besok. ${ }^{125}$

Keempat, gotong royong atau kebersamaan. Dalam hal tolong-menolong pada peristiwa kematian, biasanya dilakukan oleh seseorang dengan sangat rela, tanpa perhitungan akan mendapat pertolongan kembali, karena menolong orang yang mendapat musibah itu rupa-rupanya berdasarkan rasa bela sungkawa yang universal dalam jiwa makhluk manusia. Dan dasar dari tolong-menolong juga rupa-rupanya perasaan saling butuh membutuhkan, yang ada dalam jiwa warga masyarakat. Banyak masyarakat Kecamatan Lingsar memberikan statemen yang teologi sebagai justifikasi terhadap praktek sedekah atau melampak dalam masyarakat itu. Terutama tokoh agama

123 Wawancara dengan H. Burhanudin tanggal 17 Juli 2015.

124 Wawancara Sarawan Sukadana Tokoh Masyarakat Desa Saribaye tanggal 17 Juli 2015.

${ }^{125}$ Wawancara dengan Janiman Tokoh Masyarakat di Desa Karang Bayan Karang Bayan, Juli 2015.

\section{Copyright (C) 2019 Schemata Journal}

Available online at http://journal.uinmataram.ac.id/index.php/schemata 
Zaenudin Mansyur, Kearifan Sosial Masyarakat Sasak Melalui Tradisi Melampak di Kecamatan Lingsar...

memberikan informasi bahwa kegiatan ini berlandaskan pada firman Allah yang terkait dengan tolong menolong. Menurut Redi dalam upacara sedekah memberikan rasa kebersamaan karena semua warga akan berbondong-bondong membantu warga yang sedang melakukan upacara sedekah. Salah satu cara kebersamaan yaitu ketika melakukan gawe. Semua tetangga di sekitar akan berkumpul bersama dalam proses pembuatan jajan, memasak nasi, memasak lauk pauk untuk tamu yang akan diundang. ${ }^{126}$ Sedangkan menurut Tarpi upacara sedekah akan menimbulkan rasa kegotong royongan antar warga karena semangat kebersamaan dan peduli yang di miliki warga dalam semua hal salah satunya dalam upacara sedekah, selain itu upacara sedekah dianggap sebagai rasa saling tolongmenolong antar tetangga. ${ }^{127}$ Bapak Jeni mengatakan upacara ini memberi rasa saling tolongmenolong karena keluarga si mayit memberi bantuan untuk di sedekahkan kepada tokoh agama, tokoh masyarakat, selain itu maksud dari upacara sedekah kematian tidak lain untuk mendoakan dan mendapat keselamatan bagi si mayit. Lebih jauh menurut bapak Jeni keputusan mengadakan upacara sedekah kematian diambil berdasarkan keyakinan dan persaan khawatir yang tidak diinginkan atau akan datangnya malapetaka tetapi juga upacara sedekah diadakan karena suatu kebiasaan rutin yang dilakukan sesuai dengan kebiasaan adat. $^{128}$

\section{Analisis Tradisi Melampak sebagai Tradisi Sosial}

Salah satu tradisi dari sekian tradisi di Lombok yang masih intens dilakukan masyarakat sampai saat ini adalah upacara sedekah kematian atau lazim disebut sebagai tradisi melampak. Hal ini masih dilakukan disebabkan keinginan masyarakat yang tinggi untuk mendapatkan keselamatan dunia akhirat. Namun keinginan masyarakat kadangkadang diterpa pro-kontra disebabkan belum jelasnya hukum tentang upacara sedekah kematian ini. Masyarakat yang bijak mungkin bisa memberikan pandangan hukum yang solutif, rasioanal, dan mudah dicerna tetapi masyarakat yang suka menganggap diri benar mungkin akan memandang remeh dan selalu mencela tanpa mempelajari dan mengamati terlebih dahulu apa upacara melampak atau sedekah kematian dan hukum yang terkait dengannya.

Pro dan kontra dalam proses menetapkan legalitas formal dari praktek sedekah di kalangan umat Islam di Kecamatan Lingsar merupakan perkara yang tidak terlalu perlu

126 Wawancara dengan Redi Tokoh Masyarakat Desa Karang Bayan tanggal 18 Juli 2015.

127 Wawancara dengan Tarpi Tokoh Pemuda Desa Karang Bayan tanggal 19 Juli 2015.

${ }^{128}$ Wawancara dengan Jeni Tokoh Masyarakat Desa Karang Bayan tanggal 17 Juli 2015. 
Zaenudin Mansyur, Kearifan Sosial Masyarakat Sasak Melalui Tradisi Melampak di Kecamatan Lingsar...

untuk dpersoalkan. Karena perbedaan antara satu dengan lainnya pada perinsipnya berada di luar kehendak manusia. Artinya bagaimanapun persepsi dan respon masyarakat dalam menyatukan sebuah pendapat ternyata kandas di tengah jalan disebabkan oleh fitrah manusia yang memiliki perbedaan dengan pihak lainnya. Segelintir masyarakat yang terus menampakkan pendapat yang berbeda dalam masyarakat tidak lebih berarti bila dibandingkan dengan perbedaan pendapat para sahabat sampai pada abad keempat. Perbedaan semestinya dapat dijadikan pelajaran yang berharaga bagi umat Islam di mana saja berada, namun sekali-kali perbedaan itu tdak mesti dijadikan sebagai dasar untuk memecah belah antar satu dengan lainnnya. Konsep seperti inilah yang kemudian diandalkan oleh kaum muslim untuk memutuskan perkara hukum dalam masyarakat sehingga rahmat Tuhan tetap tercurahkan serta perpecahan dirampingkan. ${ }^{129}$

Praktek sedekah atau melampak dalam upacara kematian yang telah mentradisi dalam masyarakat Kecamatan Lingsar memiliki alasan sosial yang berbeda-beda meskipun pada prinsipnya sama. Alasan-alasan tersebut dapat dijadikan sebagai doktrin untuk melegalkannya sebagai sebuah tradisi yang tidak boleh ditinggalkan oleh masyarakat. Misalnya keabsahannya tidak bisa ditolak sebagaimana yang telah dilontarkan oleh Amaq Jumrah salah seorang masyarakat Dusun Karang Bayan Timur Desa Karang Bayan Lingsar mengatakan bahwa upacara melampak atau sedekah kematian boleh dilakukan sebab orang tua-orang tua dahulu juga melakukannya dan tidak pernah ada larangan dari siapa-siapa termasuk tuan guru. ${ }^{130}$ Selain itu, Suginten mengatakan bahwa upacara melampak atau sedekah kematian sah-sah saja dilakukan masyarakat asal masyarakat tidak melakukan sesuatu yang diharamkan agama seperti syirik, upacara sedekah kematian menurutnya tidak melanggar ajaran agama Islam sebab di dalamnya terdapat acara zikiran dan doa yang dipanjatkan kepada Allah. ${ }^{131}$

Kedua pendapat tokoh masyarakat di atas tidak merinci secara detail tentang dasar dibolehkannya tradisi sedekah tersebut namun dapat dikatakan sebagai alasan teologis. Apalagi kalau kemudian tidak bertentangan dengan syari at Islam dan memiliki kemaslahatan di dalamnya tentu alasan tersebut menjadi kuat dan argumentatif. ${ }^{132}$ Apabila secara bijak menelusuri maksud dari alasan nenenk moyangnya, terutama dalam

\footnotetext{
129 Syah Waliyullah ad-Dahlawi, Beda Pendapat di Tengah Umat Sejak Zaman Sababat sampai Abad Keempat, terj., Aziz Masyhuri (Yogyakarta: LkiS, 2010), 21.

${ }^{130}$ Wawancara dengan Amaq Jumrah Desa Karang tanggal 18.

131 Wawancara dengan Suginten Desa Gegelang , 20 Juli 2015.

132 Asgar Ali Enginer, Islam dan Teologi Pembebasan, terj. Agung Prihantoro (Yogyakarta: Pustaka Pelajar, 2003), 99.
}

\section{Copyright () 2019 Schemata Journal}

Available online at http://journal.uinmataram.ac.id/index.php/schemata 
Zaenudin Mansyur, Kearifan Sosial Masyarakat Sasak. Melalui Tradisi Melampak di Kecamatan Lingsar...

melaksanakan tradisi sedekah pada upacara kematian, maka tidak akan pernah ada ukuran hitam putih dalam melegalkannya, seperti pendapat yang menjelaskan boleh dan tidak boleh, sah dan batal, halal maupun haram. ${ }^{133}$ Tetapi respon yang muncul adalah melegalkannya atas dasar kandungan maslahat di dalamnya. ${ }^{134}$ Artinya kemaslahatan tidak hanya terbatas pada kemampuan masyarakat menjalani syari at Allah di muka bumi tetapi selebihnya memberikan manfaat dan kesejahteraan bagi pemberi dan penerima tradisi melampak atau sedekah itu. ${ }^{135}$ Dalam proses penetapan hukum oleh dua tokoh masyarakat tersebut tidak ada yang salah dan tidak yang terlalu benar, karena konsep ijtihad bersipat pleksibel dan sangat menghargai siapa saja yang melakukan ijtihad. Artinya setiap orang yang berijtihad dipastikan dapat pahala meskipun satu pahala bagi yang salah dan dua pahala bagi yang benar. ${ }^{136}$

Usman salah seorang tokoh agama Dusun Karang Bayan Barat mengatakan bahwa tradisi upacara sedekah kematian perlu ada telaah yang mendalam agar tidak terjadi salah pandangan sebab praktik ini di dalamnya terdapat kepercayaan Islam dan Hindu karena dalam melakukan upacara menggunakan kemenyan pada saat melakukan upacara. ${ }^{137}$ Menurutnya niat masyarakat adalah suatu yang paling penting ditelaah, tradisi ini sebenarnya tergantung pada niat. Jika masyarakat mengadakan ritual dengan niat berdoa kepada Allah untuk keselamatan mayit maka sah-sah saja dalam ajaran Islam. Sebaliknya jika masyarakat berniat meminta kepada selain Allah seperti meminta kepada kekuatan alatalat ritual lain maka haram hukumnya dilakukan. ${ }^{138}$ Oleh karena itu, dalam menjustifikasik upacara melampak atau sedekah kematian perlu adanya telaah dari berbagai sumber hukum

133 Al-Ghazali, al-Mustasyfa fi Tlm al-Ushul (Beirut: Dar al-Kutub al-ilmiyah, 1983), 139-140. Bandingkan dengan Abu Ishaq As-Syatibhi, al-Muwafaqat fi Ushuli as-Syari ah (Beirut: Dar al-Fikr, t.th.), 25-37. Lihat juga Muhammad al-Thair bin 'Asyur, Maqashid As-Syari ab al-islamiyah (Tunisia: t.tp, 1946), 63.

134 Najamuddin At-Thufi, Syarah al-Arba in An-Nawawi; bi Tahqiq, Ahmad Haji Muhammad Usman Makkah al-Mukarramah: al-Maktabah al-Makiyyah, 1988), 19. Bandingkan dengan Mohammad Roy Purwanto, Dekonstrusksi Teori Hukum Islam Kritik terbadap Konsep Maslahab Najamuddin at-Thufi (Yogyakarta: Kaukaba Dipantara, 2014), 98.

135 Pertimbangan untuk menjaga kesejahteraan dalam berbagai aktivitas menjadi bagian dalam menegakkan syari ${ }^{2}$ h. Menurut as-Syatibi hifz an-nafs agar terhindar dari kelaparang. Abu Ishaq al-Syatibi, $A l-$ Muwafaqat fi Ushul al-Syari ah (Beirut: Dar al-Fikr, t.th), 13. Lihat juga Jasser Auda, Maqāșid al-Sharìah as Philosophy of Islamic Law: A Systems Approach, (London: the International Institut of Islamic Thougth, 2007), xxi.

136 Ganjaran pahala bagi pelaku ijtihad di atas dapat dilihat dalam kitab-kitab ushul figh termasuk Syaikh Muhammad Khudairi Beak, Ushul al-Figh, terj., (Jakarta: Pustaka Amani, 2007), 809. Lihat juga Muchtar Yahya dan Fathurrahman, Dasar Dasar Pembinaan Hukum Fiqh Islam (Bandung: al-Ma arif, 1986) 384-385. Lihat Juga Amir Syarifuddin, Ushul Fiqh (Jakarta: Logos Wacana Ilmu, 2001), 290.

137 Wawancara dengan Usman Tokoh Agama di Desa Karang Bayan, Wawancara, Karang Bayan, 25 Juli 2015 Jam 16.00 Wita

${ }^{138}$ Lihat Ahmad Umar Hasyim, Syakhshiyat al-Muslim, terj., Joko Suryatno (Yogyakarta: Mitra Pustaka, 2004), 615.

\section{Copyright (C) 2019 Schemata Journal}

Available online at http://journal.uinmataram.ac.id/index.php/schemata 
Zaenudin Mansyur, Kearifan Sosial Masyarakat Sasak. Melalui Tradisi Melampak di Kecamatan Lingsar...

Islam baik yang bersumber dari Al-Qur'an dan Hadis ataupun dari sumber-sumber Hukum Islam yang muncul dari pemikiran (Al-Ra'yu) para ulama. Sebab upacara melampak atau sedekah kematian adalah suatu perpaduan budaya dengan agama yang banyak memunculkan persepsi masyarakat. Dalam hal ini agama sebagai alat untuk mempertahankan tradisi di Desa seperti yang dikemukakan oleh Clifford Geertz bahwa nampaknya agama dan budaya menurut Clifford Geertz merupakan dua aspek yang tidak bisa dipisahkan antara satu dengan lainnya. Dua aspek yang tidak bisa dipisahkan antara satu dengan lainnya. Upacara ritual dalam budaya tertentu dapat menampilkan simbolsimbol prilaku masyarakat yang diawali dari praktek agama. Dengan begitu, agama pada prinsipnya menurut Geertz menempati posisi yang kuat dalam memperkokoh sebuah budaya dalam masyarakat, sehingga budaya tersebut tetap hidup dalam masyarakat dan diyakini sebagai sebuah hasil karya yang terus dilestarikan. Upacara melampak menjadi kasus yang sangat relevan dengan konsep yang ditawarkan oleh Geertz ini. Pemberian keluarga yang terkena musibah berupa barang keperluan atau kebutuhan si mayat selama hidupnya terhadap sosok yang disebut Kiyai merupakan produk keyakinan mereka terhadap aturan agama yang harus banyak sedekah ketika terkena musibah. Khususnya sedekah itu dikeluarkan untuk diniatkan pahalanya kepada al-marbum dan al-marbumah.

Uraian tersebut memberikan gambaran bahwa aktivitas tersebut sangat bersifat sosiologis. Karena semangat dan usaha masyarakat Kecamatan Lingsar dalam memberikan pertolongan terhadap orang yang berjasa dalam hal ini kiyai merupakan aspek kekuatan prinsip sosial yang tertanam dalam kepribadian mereka. ${ }^{139}$ Bahkan usaha tokoh adat dan tokoh masyarakat mencantolkannya sebagai kegiatan keagamaan setidaknya menjadi aktivitas sosial untuk dilestarikan sebagai kegiatan sosial dalam masyarakat. ${ }^{140}$ Sebuah hadis yang cukup tidak asing di kalangan umat Islam adalah dapat dijadikan argumen yang kuat untuk melegalkan tradisi sedekah itu memiliki azas sosial yang berbeda. Rasulullah saw bersabda pada redaksi hadis berikut di bawah ini. Disebutkan di dalam hadis shahih dari Abi Hurairah R.A bahwasanya Nabi SAW besabda:

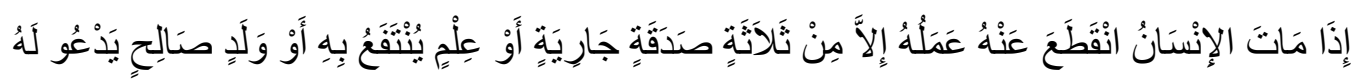

139 Siklus perubahan dalam pelaksanaan tradisi melampak tidak lebih sebagai perwujudan perubahan social yang terjadi dalam masyarakat. Artinya jika melampak terus dipraktekkan maka nilai tolong menolng semakin kuat dalam masyarakat. Lihat Pioter Sztomka, The Sociology of Social Change (UK: Blawell Publishers, 1994). Lihat juga Nanang Martono, Sosiologi Perubahan Sosial Perspektif Klasik, Modern, Posmodern, dan Poskolonial (Bandung: Aditya Utama, 2007), 12.

140 Beni Ahmad Saebani, Sosiologi Hukum (Bandung: Pustaka Setia, 2007), 133. Bandingkan dengan Saifullah, Refleksi Sosiologi Hukum (Bandung: Aditya Gama, 2007), 25-27. 
Zaenudin Mansyur, Kearifan Sosial Masyarakat Sasak Melalui Tradisi Melampak di Kecamatan Lingsar...

Artinya Apabila manusia meninggal dunia, terputuslah segala amalannya, kecuali dari tiga perkara: shadaqah jariyah, ilmu yang bermanfaat atau anak shaleh yang mendoakannya". (HR. Muslim). ${ }^{141}$

Dalam lain, yaitu riwayat Ibnu Majah dari Abu Qatadah Radhiyallahu 'anhu, dia berkata: Rasulullah SAW bersabda:

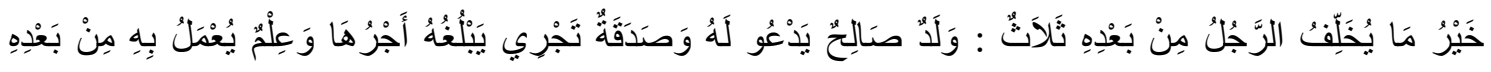
Artinya:"Sebaik-baik apa yang ditinggalkan oleh seseorang setelah kematiannya adalah tiga perkara: anak shalih yang mendo'akannya, shadaqah mengalir yang pahalanya sampai kepadanya, dan ilmu yang diamalkan orang setelah (kematian) nya". ${ }^{142}$

Dari sekian redaksi hadis di atas dapat ditarik suatu gambaran bahwa kegiatan praktek melampak atau sedekah dalam upacara kematian yang dipraktekkan oleh masyarakat Kecamatan Lingsar adalah benar-benar memiliki nilai sosial yang tinggi. Dengan demikian tidak heran kalau kemudian pihak masyarakat miskin dan membutuhkan mengklaim bahwa praktek melampak itu mengandung nilai-nilai sosial yang tinggi. Nilai silaturahmi serta inisiatif untuk saling membantu tercermin dalam kondisi seseorang jika ia mempraktekkannya. Sementara saling bantu dan memberikan merupakan kewajiban seseorang dengan orang lain dalam bertetangga. Banyak cara yang dapat dilakukan seseorang untuk membantu saudaranya seperti melakuakan sedekah. Tetapi sedekah disini tidak seperti yang dibayangkan oleh setiap orang berupa materi semata. Tetapi sedekah itu lebih pada sebuah kebaikan yang disuguhkan kepada orang lain dan penerima dalam menerimanya tetap menampakkan sikap lapang dada. Secara tidak langsung bahwa sedekah itu berjenjang sekaligus jenjang itu sebagai tugas pokoknya, misalnya sedekah lisan, perbuatan, dan sedekah amal jariyah.

Dalam melegalkan sedekah upacara kematian di Kecamatan Lingsar sebagai tradisi sosial tentunya harus menelusuri serta mengkaji secara mendalam nilai-nilai atau muatan sosial yang terkandung di dalamnya. Secara tidak langusung semua pihak masyarakat ikut terlibat dalam memberikan pertolongan maupun bantuan. Misalnya dalam tahap meninggalnya individu masyarakat pada saat itu praktek sosial semisal sedekah terus dilaksanakan. Hal ini dapat dicermati dari semangat masyarakat berduyun-duyun untuk memberikan sumbangan kepada keluarg yang trkena musibah. Sedangkan pemberian berupa sumbangan materi kepada orang lain dapat dikatagorikan sebagai ssedekah

\footnotetext{
${ }^{141}$ Ibnu Hajar Al-Asqalani, ter. Abu Mujaddidul Islam Mafa, Terjemah Bulughul Maram, (Surabaya, Gita Media Press, 2006), 457.

142 Ibid, , 458
}

\section{Copyright (C) 2019 Schemata Journal}

Available online at http://journal.uinmataram.ac.id/index.php/schemata 
Zaenudin Mansyur, Kearifan Sosial Masyarakat Sasak Melalui Tradisi Melampak di Kecamatan Lingsar...

perbuatan sebagaimana yang dijelaskan dalam al-Qur`an maupun hadis Rasulullah saw. Terdapat salah satu hadis yang cukup relevan untuk dijadikan sebagai doktrin, yaitu sebagaimana sabdanya berikut ini;

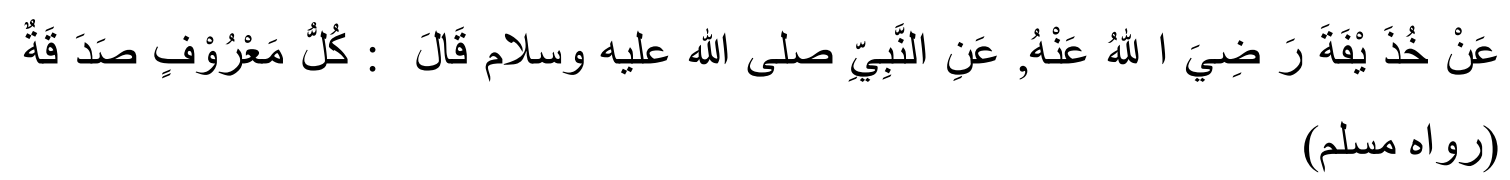

Artinya: Diriwayatkan dari Huzaifah r.a., dari Nabi saw. Beliau bersabda: setiap kebaikan adalah sedekah.” (HR. Muslim). ${ }^{143}$

Dari penjelasan hadis tersebut memberikan ilustrasi bahwa setiap perbuatan baik yang dilakukan oleh sesorang untuk menyenangkan orang lain secara suka rela maka bisa dipasttikan perbuatannya itu sebagai sedekah. Apalagi kalau mencermati semangat masyarakat di Kecamatan Lingsar dengan memberikan beras dan uang kepada keluarga yang terkena musibah maka sudah barang tentu perbuatan yang dilakukan adalah sedekah. Dengan demikian, praktek-praktek ini setidaknya memberikan konstribusi dalam memperkuat aktivtas sedekah dalam upacara kematian itu sebagai tradisi sosial yang harus dilestarikan.

Dasar untuk memperkuat praktek sedekah sebagai tradisi sosial yang wajib dilaksanakan oleh masyarakat di Kecamatan Lingsar adalah ketika mencermati praktek sedekah yang tidak hanya terhenti dengan melakukan tradisi belangar itu, namun perbuatan sedekah juga berlaku bagi jamaah laki mulai dari tahap penguburan sampai malam kesembilan dengan mengadakan zikir atau tahlilan dan do `a yang pahalanya diniatkan untuk dikirim kepada al-marbum maupun al-marhumah. Praktek tersebut setidaknya dapat dikatagorikan sebagai sedekah lisan karena tidak lebih yang berbuat kebaikan itu adalah lidah. Sementara perkataan baik yang muncul dari orang tertentu merupakan sedekah. Banyak ayat-ayat al-Qur`an maupun hadis Sabda Rasulullah yang menjelaskan perbuatan lisan dapat dijadikan sebagai sedekah. Salaha satu ayat al-Qur`an dapat dilihat dari penjelasan al-Qur`an Allah SWT. berfirman;

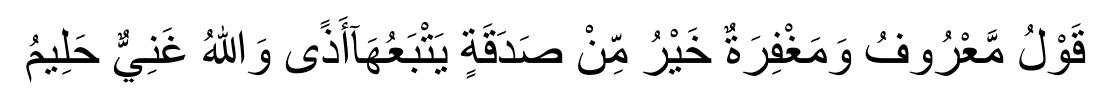

Artinya: Perkataan yang baik dan pemberian maaf lebih baik dari sedekah yang diiringi dengan sesuatu yang menyakitkan (perasaan si penerima). Allah Maha Kaya lagi Maha Penyantun. ${ }^{144}$

\footnotetext{
${ }^{143}$ Imam Al-Mundziri. Ringkasan Shabih Muslim. Cet 2, (Jakarta: Pustaka Al-Amani, 2003), 310

144 QS. Al-Baqarah (2): 263
} 
Zaenudin Mansyur, Kearifan Sosial Masyarakat Sasak Melalui Tradisi Melampak di Kecamatan Lingsar...

Dengan mencermati penjelasan ayat di atas, dapat disimpulkan bahwa segala sesuatu yang muncul dari lidah yang memberikan kebaikan kepada orang lain merupakan sedekah. Pemberian ta`ziyah, zikir serta do`a yang diniatkan pahalanya kepada yang meninggal dunia merupakan amal sosial yang akan memperkuat praktek sedekah di kalngan masyarakat Kecamatan Lingsar sebagai tradisi sosial yang harus dipertimbangkan. Apalagi kalau mencermati pihak kiyai atau tuan guru dalam memberikan ta ‘iyah dan tasammuh. Di sela-sela itu sering mengajak masyarakat secara lisan untuk mempersaksikan al-marbum dan al-marbumah sebagai orang yang baik (syahadatal khair). Bahkan dalam penyampaian ta ziyah dan tasammub itu adalah mengajak masyarakat untuk mema`afkannya selama ia bergaul dengan orang lain. ${ }^{145}$

Sedekah pada hakikatnya adalah terdapat imbal balik antara pemberi dan penerima, meskipun dalam aturan agama dikehendaki adanya suka rela tanpa adanya harapan balasan dari orang yang telah diberi. ${ }^{146}$ Dalam mengkajinya secara mendalam bahwa sedekah itu tetap adanya balasan bagi yang memberikan. Sedekah upacara kematian atau sering disebut melampak dalam masyarakat Kecamatan Lingsar adalah aktivitas yang melahirkan balas membalas antara kedua belah pihak yang melaksanakannya, yakni keluarga yang terkena musibah dan masyarakat setempat. Dimana masyarakat akan mendapatkan balasan dari pihak keluarga yang terkena musibah dalam hal upacara ngunjuran, nelung, meituk, dan nyiwak. ${ }^{147}$ Semua masyarakat ikut terlibat bekerja sama untuk membantu keluarga duka dalam mempersiapkan hidangan makanan yang akan diperuntukkan kepada masyarakat yang memberikan zikir dan do`a restu kepada al-marbum dan al-marbumah. Pemberian balas jasa kepada masyarakat dari keluarga duka berlanjut dengan pemberian sedekah kematian atau melampak, yaitu pemberian pihak keluarga berupa kebutuhan selama hidupnya yang diserahkan kepada masyarakat yang diwakili oleh tokoh agama atau Kiyai setempat. Pemberian tersebut dilakukan atas dasar sukarela tanpa harus menghendaki balasan dari Kiyai yang menerima. Namun pemberian itu dihajatkan sebagai wujud keprehatinan

145 Praktek-praktek social tidak hanya dalam bentuk aktivitas jasmani tetapi aktivitas lisan jauh lebih bermanfaat jika mitra social merasa nyaman dan aman dengannya. Lihat Charles Issnawi, Ibnu Khaldun: An Arab Philosophy of History, London: John Murray, 1950), 67.

146 Pentingnya pelaksanaan aktivitas social seperti sedekah zakat dapat dilihat ketegasan Abu Bakar dalam mengambil langkah tegas untuk memerintahkan kaum muslim untuk membayar zakat termasuk kepada masyarakat Badui yang kembali memperlihatkan tanda tanda pembangkangannya sepeninggal Rasulullah saw. Muhammad Hasan, Manjemen Zakat Model Pengelolaan yang Efektif (Yogyakarta: IDEA Press,2011), 11.

147 Soenyata Kartadarmadja dan Sutrisno Kutoyo, ed, Sejarah Kebangkitan Nasional Daerah NTB (Mataram: Pusaat Penelitian Sejarah dan Budaya Depdikbud, 1978), 27-29. Bandingkan Zaki, Tradisi Islam Suku Sasak di Bayan Lombok Barat, Studi Historis tentang Islam Wetu Telu 1890-1965, Skripsi (Yogyakarta: IAIN Sunan Kalijaga Yogyakarta), 10.

\section{Copyright () 2019 Schemata Journal}

Available online at http://journal.uinmataram.ac.id/index.php/schemata 
Zaenudin Mansyur, Kearifan Sosial Masyarakat Sasak Melalui Tradisi Melampak di Kecamatan Lingsar...

keluarga duka kepada masyarakat yang telah membantunya selama mengadakan upacara. Aktivitas aktivitas ini merupakan perwujudan dari realitas cultur masyarakat yang antusias dalam melestarikan tardisi sosial. Paling tidak dengan adanya praktek sedekah dalam upacara kematian sebagai bagian terkecil untuk memotivasi diri dalam mengimplementasikan fitrah sosial yang telah tertanam dalam dirinya. Karena setiap amal perbuatan baik yang disuguhkan kepada seseorang tertentu sampai orang itu berbuat baik kepada orang lain lagi merupakan amal sosial yang disebut amal jariah menurut bahasa agama. Salah satu hadis yang lazim dijadikan doktrin terhadap amal jariah seseorang adalah Rasulullah bersabda;

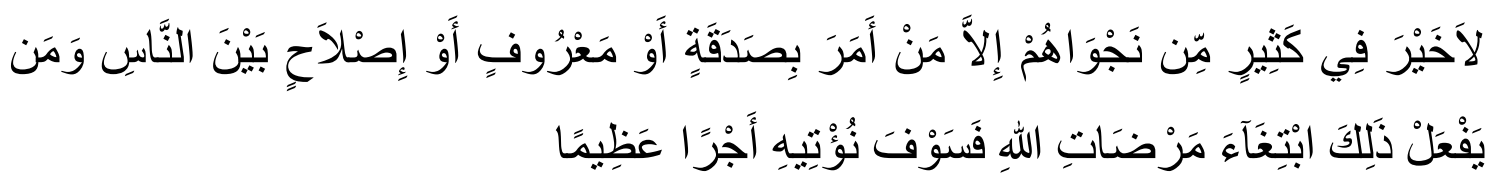

Artinya: Tidak ada kebaikan pada kebanyakan bisikan-bisikan mereka, kecuali bisikanbisikan dari orang yang menyuruh (manusia) memberi sedekah, atau berbuat ma'ruf, atau mengadakan perdamaian di antara manusia. dan Barangsiapa yang berbuat demikian karena mencari keredhaan Allah, maka kelak Kami memberi kepadanya pahala yang besar. $^{148}$

Dari gambaran hadis tersebut dapat ditarik suatu kesimpulan, bahwa segala amal baik yang disebabkan oleh lidah, perbuatan, hati yang dicerminkan dengan sikap baik kepada orang lain merupakan amal jariah yang melahirkan keridhaan Allah sebagai balasannya. Tidak terkecuali praktek melampak atau sedekah yang selama ini dipraktekkan oleh masyarakat Kecamatan Lingsar. Segala prosesi dari tahap pertama sampai terakhir merupakan amal baik yang dilakukan oleh masyarakat melalui kerjasama. Perbuatan mereka itu, setidaknya dapat diklaim sebagai perbuatan yang akan menyalamtnya dari dunia sampai akhirat meskipun Allah sendiri yang menentukan segala-galanya. Tetapi kalau melihat redaksi akhir dari hadis di atas setiap amal sosial seperti sedekah yang ditradisikan menjadi tradisi sosial maka aktivitas tersebut dapat dipastikan akan mendapatkan ganjaran yang amat beasar. Atas dasar itulah kemudian aktivitas tersebut menjadi dasar yang kuat untuk mendukung tradisi sedekah pada upacara kematian di Kecamatan Lingsar itu sebagai tradisi sosial yang harus dilestarikan.

148 QS. An-Nisa (4): 114

\section{Copyright (C) 2019 Schemata Journal}

Available online at http://journal.uinmataram.ac.id/index.php/schemata 
Zaenudin Mansyur, Kearifan Sosial Masyarakat Sasak Melalui Tradisi Melampak di Kecamatan Lingsar...

\section{KESIMPULAN}

Praktek melampak atau sedekah dalam upacara kematian yang lazim dipraktekkan masyarakat Kecamatan Lingsar dilakukan dengan tahapan, yaitu tahap penyediaan bahan kebutuhan, misalnyanya kembang rampai, dulang/andang-andang, air wangi, lekesan, beras putek, kemek, kepeng tepong. Setelah bahan bahan ritual tersebut sudah disiapkan, dilakukan tahapan proses, yaitu pertama, prosesi pembuka, yaitu upacara sedekah kematian atau melampak dimulai dengan acara zikiran (Roab) yang dihadiri oleh keluarga, tetangga, masyarakat dan tokoh agama yang dilakukan pada malam hari terhitung sejak hari pertama kematian sampai malam kesembilan. Kedua, proses inti, yaitu membawa barang-barang yang telah diserahkan kepada tokoh agama, tokoh masyarakat serta orang yang dianggap penting untuk diberikan kepadanya sebagai imbalan karena telah mendoakan si mayit. Ketiga, prosesi penutup adalah pembagian barang-barang sedekah dengan cara berjalan (lampak) menuju ke rumah kiyai, tokoh agama, dan tokoh masyarakat yang sudah dibacakan doa berupa barang-barang kesukaan si mayit semasa hidupnya dan akan di serahkan kepada orang yang sudah ditunjuk oleh keluarga si mayit.

Adapun faktor yang melatar belakangi praktek melampak menjadi tradisi yang terus dilaksanakan adalah adalah faktor kehawatiran kalau tradisi tersebut punah, warisan nenek moyang yang harus dilestarikan, dan penanaman prinsip gotong royong dalam masyarakat. Dengan demikian dapat dismpulkan bahwa praktek melampak atau sedekah dalam upacara kematian masyarakat Kecamatan Lingsar didominasi oleh kekuatan pemahaman secara teologis, antropologis, dan sosiologis. Teologis artinya masyarakat menganggap bahwa praktek melampak atau sedekah itu adalah tidak bertentangan dengan syari ah. Antropologis adalah tradisi yang harus dilestarikan karena diterima sebagai warisan nenek moyang. Sedangkan sosiologis adalah adanya semangat gotong royong, tolong menolong, terjalinnya silaturrahim dalam masyarakat.

\section{DAFTAR PUSTAKA}

Al-Fasi, Maqashid al-Syari ah al-Islamiyyah wa Makarimuba, t.t : Maktabat al-Wihdat alArabiyyat, th.

Arifin, B., (1996) Perkembangan Hukum Islam di Indonesia, Jakarta: Gema Insani Press. Bisri, C.H., (2004) Pilar-Pilar Penelitian Hukum Islam dan Pranata Sosial, Jakarta: Raja

Grapindo Persada.

Bartholomew, J., (2001) Alif Lam Mim: Kearifan Masyarakat Sasak, terj. Imron Rosyadi, Yogyakarta: Tiara Wacana Yogya.

\section{Copyright $\odot 2019$ Schemata Journal}

Available online at http://journal.uinmataram.ac.id/index.php/schemata 
Zaenudin Mansyur, Kearifan Sosial Masyarakat Sasak. Melalui Tradisi Melampake di Kecamatan Lingsar...

Cederrooth, (1981). The Spell of the Ancestors and the Power of Makkah: A. Sasak Community on Lombok, Goreborg Sweden: ACTA Universitatis Gothoburgensis.

Damin, S., (2002). Menjadi Peneliti Kualitatif, Bandung: Pustaka Setia.

Departemen Agama RI, (1985). Al-Qur`an dan Terjemahnya, Jakarta: CV Toha

Putra.

Donnelly, J. H., dkk., (1998). Fundamentals of Manajement, New York: Irwin Mc Graw-Hill.

Geertz, C., (1960). The Religion of Java, Glencoe II: The Free Press.

--- (1973). The Interpretation of Culture, New York: Basic Group.

Hasbalah, A., (1976). Usbul at-Tasyri al-Islam, Mesir:Dar al-Ma `arif.

Hoebel, A., (1959). Man in The FrimitifWorld An Introduction, New York: Mc. Gam Hill.

Haris, T., (1978). Islam Wetu Telu Sedikit tentang Sejarah dan Ajarannya Jakarta: UI Press.

Khallaf, A. W., (1998). Ilmu Ushul Fiqh, Kuwait: Dar al-Qqalam.

, (1994). Kaidah Kaidah Hukum Islam, Ilmu Ushul Fiqh, ter., Iskandar al-

Barsany, dkk. , Jakarta: Raja Wali Press.

Mazkur, M. S., (1964). Madkhal Fiqih al-Islam, Kairo, Dar al-Qaumiyyah.

Mclever, R.M. \& Page, C.H. (1937). Society: An Introduktory Analysis, New York: Rineheartan Company.

Merton, R. K., (1968).Social Theory and Social Structure, New York: Free Press.

Moleong, L. J., (2000). Metodologi Penelitian Kualitatif, Bandung: Remaja Rosdakarya.

Mudzhar, A., (1999). Studi Hukum Islam dengan Pendekatan Sosiologis, Yogyakarta: IAIN Sunan Kalijaga Press.

Qardawi, Y., (1994). Awami al-Sa ab Wa al-Murunah fi al-syari ab al-Islamiyah Bayna al-Inæibath wa al-Infirat, Kairo: Dar al-Tauzi wa al-Nasyr al-Islamiyyah.

--------, (1996). Awami as-Sa ab wa al-Murunah fi al-Syari ah al-Islamiyah, Kairo: Daar at-Tauzi wa an-Nasyr al-Islamiyah.

------- (1994). Al-Ijtihad al-Ma ashir Baina al-Inzibath wa al-Ifirat, Kairo: Daar atTauzi wa an-Nasyr al-Islamiyah.

Ritzer, G., ed. (2004). Encyclopedia of Social Theory, Vol. 1. Sage Publications, Thousand Oaks, London.

Shiddiqi, N., (1997). Fiqih Indonesia, Penggagas dan Gagasannya, Yogyakarta: Pustaka Pelajar. Soekanto, S., (2004). Pokok - Pokok Sosiologi Hukum, Jakarta: PT. Raja Grapindo Persada. Suhartono, I., (1998). Metode Penelitian Sosial, Bandung:Remaja Rosdakarya.

Suparlan, P., (1998). Tradisi Baru Penelitian Agama Islam: Tinjauan antara Disiplin Ilmu, Jakarta: Pusjarlit.

Syarifuddin, A., (2001). Ushul Fiqh, Jakarta: Logos Wacana Ilmu.

Tono, S. dkk, (1998). Ibadah dan Akblak dalam Islam, Yogyakarta: UII Press.

Ulwan, A. N., (1992). Syari at Islam: Hukum yang Abadi, terj., Daut Rasyid, Jakarta: Usamah Press.

Zahrah, M. A., (2003). Ushul Fiqh, Jakarta: Pustaka Pirdaus.

Zakaria, F., (1998). Muzaik Budaya Orang Mataram, Mataram: Yayasan Samuremas AlHamidi. 